\title{
Raiva: uma breve revisão
}

\author{
Rabies: a brief review
}

Helena Beatriz de Carvalho Ruthner Batista ${ }^{1}$, Ana Cláudia Franco ${ }^{1} \&$ Paulo Michel Roehe $^{1,2}$

\begin{abstract}
RESUMO
Provavelmente todas as espécies animais de sangue quente são passíveis de serem infectadas pelo vírus da raiva (VR). No entanto, a maioria dessas espécies, quando infectadas, tornam-se hospedeiros finais do agente, pois a infecção resulta em morte e não ocorre disseminação do mesmo para novos hospedeiros. Para garantir sua perpetuação na natureza, o VR adaptou-se a determinadas espécies, denominadas "hospedeiros naturais", as quais servem como reservatórios do vírus. Durante esse processo de adaptação, modificações genômicas e antigênicas são geradas, originando as chamadas "variantes" do VR. Estas por vezes apresentam alterações que podem ser utilizadas como marcadores epidemiológicos, permitindo, por exemplo, a identificação da espécie fonte de infecção ou de variantes associadas a determinados nichos ecológicos. Nesta breve revisão são apresentados dados sobre o VR e sobre a ocorrência de variantes no Brasil, com ênfase nos achados de uma parcela dos inúmeros estudos realizados sobre o tema. São também apresentados e discutidos dados epidemiológicos sobre a situação da raiva no País nos últimos dez anos (1997-2006), salientando-se a marcada redução no número de casos de raiva urbana em cães e em humanos, estes últimos infelizmente compensados por um aumento no número de casos humanos associados a contatos com morcegos hematófagos no triênio 2004-2006.
\end{abstract}

Descritores: Raiva, Brasil, revisão, variantes, epidemiologia.

\section{ABSTRACT}

Probably all warm blooded animals are susceptible to rabies virus (RV) infections. However, most of these species will end up as terminal hosts for the virus, since a fatal outcome is the rule and usually no virus dissemination from such hosts occur. Nevertheless, in nature, RV has become adapted to certain species, referred to as "natural hosts", which act as reservoirs for the virus. During the process of virus adaptation to such hosts, genomic and eventually antigenic modifications are generated that can be used as markers which may help to identify the natural host which acted as source of infection, along with other characteristics peculiar to such modified viruses, denominated RV "variants". Such variants may bear alterations that can be used as epidemiological markers, allowing for instance the identification of the source of infection or the establishment of associations between a particular variant and a defined ecological niche. In this brief review, some of the recent data on the virus and the occurrence of variants are presented, with emphasis on the findings of a parcel of the various studies on the subject that have been carried out in Brazil. Epidemiologic data on reported cases of rabies in the country in the last ten years (1997-2006) are presented and discussed, highlighting the marked decrease in the numbers of urban cases of rabies in dogs and humans, what was unfortunately compensated by an increase in the number of human cases associated to vampire bat transmission in the trienium 2004-2006.

Key words: rabies, Brazil, review, variants, epidemiology. 


\section{INTRODUÇÃO}

\section{O AGENTE}

1. Resistência a agentes físico-químicos

\section{Estrutura do vírion}

\section{Replicação viral}

4. Variabilidade entre amostras de vírus

\section{PATOGENIA E SINAIS CLÍNICOS}

\section{Transmissão}

2. Período de incubação

\section{Replicação no hospedeiro}

4. Sinais clínicos

\section{EPIDEMIOLOGIA}

1. Ciclos da raiva

2. Ciclo urbano

3. Ciclo aéreo

\section{Ciclo silvestre}

\section{SITUAÇÃO DA RAIVA NO BRASIL}

\section{Raiva urbana}

\section{Raiva em morcegos e animais silvestres}

\section{Raiva em humanos}

\section{Raiva dos herbívoros}

\section{DIAGNÓSTICO}

\section{Diagnóstico virológico}

2. Diagnóstico sorológico

\section{PREVENÇÃO E CONTROLE}

\section{INTRODUÇÃO}

A raiva é uma das mais antigas doenças reconhecidas pela humanidade, muitas vezes misturandose com o folclore e crenças religiosas, dando origem a mitos e lendas [149]. Como alvo de estudos científicos, o volume de informação sobre raiva cresceu de tal forma que se torna praticamente impossível acompanhar tudo o que tem sido publicado sobre o assunto. Apesar disso, são muitas as lacunas no conhecimento da biologia do vírus, sua multiplicação e seus mecanismos de adaptação aos hospedeiros. No Brasil, a raiva vem sendo estudada desde os tempos de Carini, em 1911 [22], tendo a quantidade de publicações sobre o tema atingido proporções impressionantes nas últimas décadas. Por tratar-se de um vírus muito estável antigenicamente, a identificação das chamadas "variantes" antigênicas e genotípicas têm concentrado a atenção de muitos pesquisadores, razão pela qual se buscou focalizar esse tema nessa breve revisão. Além disso, são apresentadas informações epidemiológicas sobre a evolução da infecção no Brasil nos últimos dez anos.

\section{O AGENTE}

$\mathrm{O}$ vírus da raiva (VR) pertence à ordem Mononegavirales, família Rhabdoviridae, gênero Lyssavirus [60]. Este gênero (do grego lyssa, que significa raiva) 
inclui alguns outros vírus denominados "vírus relacionados à raiva", os quais apresentam semelhanças antigênicas com o VR e têm sido isolados de quirópteros. Os lissavírus de quirópteros são aparentemente mais antigos evolutivamente do que os lissavírus de carnívoros. O VR provavelmente foi originado por eventos de troca de hospedeiros que ocorreram a partir de lissavírus de morcegos [10,53]. O gênero Lyssavirus é presentemente subdividido em sete genótipos. O VR é classificado como genótipo "1", sendo o protótipo do gênero [155]. Além desses, outros quatro novos genótipos foram propostos recentemente, representados pelos vírus Aravan, Khujand, Irkut e West Caucasian $[8,81,166]$. Os membros do gênero Lyssavirus e sua distribuição geográfica estão listados na Tabela 1.

\section{Resistência a agentes físico-químicos}

O VR é envelopado e, como tal, sensível a detergentes e solventes lipídicos (éter, clorofórmio). Sua resistência fora do hospedeiro é baixa. O vírus é rapidamente inativado a temperaturas altas, sendo destruído a $50^{\circ} \mathrm{C}$ durante 15 minutos. É sensível ao dessecamento, luz solar, radiação ultravioleta, hipoclorito de sódio, soda cáustica a $2 \%$, sabões, detergentes, formalina a $10 \%$, glutaraldeído a $2 \%$, fenóis a $5 \%$, cresóis e ácidos e bases em extremos de $\mathrm{pH}$. $\mathrm{O}$ vírus se mantém estável por longos períodos a $4^{\circ} \mathrm{C}$, se conservado a $-20^{\circ} \mathrm{C}$ em tecidos mergulhados em glicerina tamponada, o vírus se mantém por vários anos [95].
$\mathrm{A}-70^{\circ} \mathrm{C}$ ou temperaturas mais baixas, o vírus se mantém viável indefinidamente.

\section{Estrutura do vírion}

A partícula completa do vírus rábico (denominada vírion) apresenta um formato característico que lembra uma bala de revólver, com um diâmetro de aproximadamente $75 \mathrm{~nm}$ e comprimento entre 100 e $300 \mathrm{~nm}[33,95]$. $\mathrm{O}$ vírion apresenta-se como um denso cilindro formado pelo genoma disposto em formato de mola e envolto em uma proteína denominada nucleoproteína $(\mathrm{N})$; este conjunto forma um nucleocapsídeo helicoidal, com o RNA e a proteína $\mathrm{N}$ fortemente unidos [7,65]. O nucleocapsídeo e algumas moléculas de outras três proteínas estruturais ( $\mathrm{P}, \mathrm{M}$ e L) são circundados por um envelope, o qual é derivado das membranas celulares. Neste envelope estão inseridas moléculas de uma glicoproteína trimérica, denominada " $G$ ", cujas moléculas o atravessam e são projetadas para a parte externa do vírion [7].

O genoma viral é constituído por uma cadeia de RNA de fita simples, com tamanho aproximado de $12 \mathrm{~Kb}$ e com uma massa molecular de 4,6 x $10^{6}$ $\mathrm{KDa}[144,167]$. O genoma codifica cinco proteínas, na seguinte ordem: a nucleoproteína $(\mathrm{N})$, a fosfoproteína (P previamente denominada M1), a proteína da matriz (M, previamente denominada $\mathrm{M} 2$ ), a glicoproteína $(\mathrm{G})$ e a RNA polimerase RNA viral-dependente (L). O gene conta ainda com duas regiões intergênicas não codificantes: uma delas está situada entre os genes que

\begin{tabular}{lcc} 
Tabela 1. Membros do gênero Lyssavirus: classificação genotípica e distribuição geográfica. \\
\hline Genótipos do VR & $\begin{array}{c}\text { Nome do vírus } \\
\text { representativo }\end{array}$ & Distribuição geográfica \\
\hline Genótipo 1 & Raiva & Mundial \\
Genótipo 2 & Lagos bat & África \\
Genótipo 3 & Mokola & África \\
Genótipo 4 & Duvenhage & África \\
Genótipo 5 & $\begin{array}{c}\text { European Bat } \\
\text { Lyssavirus 1 (EBL1) }\end{array}$ & Europa \\
Genótipo 6 & $\begin{array}{c}\text { European Bat } \\
\text { Lyssavirus 2 (EBL 2) } \\
\text { Genótipo } 7\end{array}$ & Australian Bat \\
Lyssavirus (ABL) & Europa \\
Novos genótipos propostos & Aravan* Khujand, & Austrália \\
\hline Fonte: $20 ; 4 ; 51 .{ }^{* *} 8 ; 162$. & Irkut, West Caucasian & Ásia central
\end{tabular}


codificam M e G e a outra entre os genes que codificam $\mathrm{G}$ e L. Esta última foi previamente chamada "pseudogene", mas trata-se de uma região não codificante, indicativa de relações evolutivas com outros vírus de genoma de RNA não segmentado de polaridade negativa, como os membros da família Paramyxoviridae $[154,156,167]$.

A glicoproteína G (525 aminoácidos, 65-70 $\mathrm{KDa})$ é responsável pela adsorção do vírus à célula hospedeira e pela fusão do envelope viral à membrana citoplasmática [98]. Além disso, G é a principal responsável pela indução de anticorpos neutralizantes, especialmente por sua porção externa ao envelope, denominada domínio antigênico ou ectodomínio [93, 167]. Alguns sítios de G, como a $\operatorname{Arg}^{333}$, estão relacionados com a patogenicidade da amostra [39]. A glicoproteína $\mathrm{G}$ é ainda capaz de estimular, em conjunto com as proteínas $\mathrm{N}$ e $\mathrm{P}$, células $\mathrm{T}$ auxiliares e citotóxicas, gerando uma resposta imune celular, além de participar do processo de brotamento de novos vírions [72,98,155]. A expressão da glicoproteína $G$ parece estar inversamente associada à indução de apoptose e à inibição da atividade da proteína $\mathrm{N}$ no transporte axoplásmico, ou seja, quanto maior a expressão de $\mathrm{G}$ em determinada amostra viral, mais apoptose e maior inibição do transporte viral nos neurônios, resultando em menor patogenicidade [102].

Apesar da glicoproteína G ser imunodominante, a proteína $\mathrm{N}$ também é capaz de induzir anticorpos neutralizantes [167]. N (450 aminoácidos, 58$62 \mathrm{KDa}$ ) é a mais conservada dentre as proteínas dos lissavírus [92]. Como citado anteriormente, $\mathrm{N}$ forma o capsídeo e está intimamente associada ao RNA viral, protegendo-o da ação de ribonucleases [154]. $\mathrm{N}$ desempenha outras atividades importantes; é fundamental na regulação da transcrição do RNA viral, participando ativamente na encapsidação de novas moléculas de RNA genômico sintetizadas, na transcrição do genoma viral e no transporte axoplásmico intraneuronal [7,102]. Além disso, a proteína $\mathrm{N}$ apresenta regiões que são importantes epitopos para o reconhecimento de linfócitos T [39].

A proteína L (2128 aminoácidos, $190 \mathrm{KDa})$, é uma subunidade do complexo que forma a RNA polimerase, que juntamente com $\mathrm{P}$ e $\mathrm{N}$ formam o conglomerado que transcreve o genoma viral [7]. Além dessa, desenvolve várias outras atividades enzimáticas, como a formação do "cap", metilação, poliadenilação, atividade de proteína quinase, além de estar envolvida na inicialização da cadeia de RNA [154]. A proteína L necessita interagir com $\mathrm{P}$ para tornar-se ativa [92]. A proteína $\mathrm{P}$ (298 aminoácidos, 35-40 KDa) é a menos conservada entre os lissavírus; encontra-se associada ao ribonucleocapsídeo e interage com L. A proteína $\mathrm{P}$ liga-se à dineína intracitoplasmática e está envolvida no transporte axonal do vírus. A proteína M (203 aminoácidos, 22-25 KDa), por sua vez, preenche o espaço entre o ribonucleocapsídeo e o envelope. É a proteína que promove a montagem das partículas, aproximando membranas, RNP e G, exercendo um papel ativo no brotamento dos novos vírions [98].

\section{Replicação viral}

A adsorção do vírus à célula hospedeira é mediada pela proteína G. Trímeros de G interagem com os receptores celulares e levam à fusão e internalização dos vírions $[28,29,156]$. Não parece haver um receptor específico para o VR; além disso, possivelmente, diferentes células utilizam diferentes tipos de receptores para permitir a penetração do vírus. Alguns estudos evidenciaram a adsorção à receptores de acetilcolina [50,84]; outros observaram que oligossacarídeos e lipoproteínas, como o ácido siálico de gangliosídeos, podem também ter participação na adsorção [153]. As moléculas de adesão celular neurais ("Neural Cell Adhesion Molecule", ou NCAM) [154], assim como a proteína denominada "receptor de neurotrofinas p75" (p75NTR) foram também apontadas como possíveis receptores para o VR [159]. Após a adsorção à célula hospedeira, o vírion penetra na célula por fagocitose, sendo englobado por uma vesícula formada às expensas da membrana celular, vesículas estas ricas em uma proteína denominada clatrina. Eventualmente, lisossomos fundem-se à vesícula contendo o vírion, liberando a RNP no citoplasma celular e permitindo que seja iniciado o processo de replicação $[153,156]$.

Uma vez no interior da célula, o genoma de polaridade negativa deve ser inicialmente transcrito para dar início à produção de proteínas. Para tanto, a RNA polimerase viral transcreve o genoma em um RNA líder e cinco mRNAs, todos os cinco com "cap" e poli-adenilados, tal como os mRNA celulares. A transcrição diminui sua eficiência em cerca de $30 \%$ nas junções dos genes N-NS, NS-M e M-G, resultando em um efeito cumulativo na expressão gênica, ou seja, a expressão é mais eficiente na extremidade 3' do genoma [68]. Estes, por sua vez, são traduzidos nas proteínas N, P, M, G e L, em ribossomos livres no 
citoplasma. A proteína G, que requer glicosilação, recebe seus carboidratos no retículo endoplasmático rugoso e é então transportada via aparato de Golgi para a membrana citoplásmica $[153,156]$.

Por outro lado, é necessário que ocorra a replicação do genoma viral para formar os novos vírions. Isso se dá somente após a tradução dos mRNAs. A proporção entre a quantidade de RNA e da proteína $\mathrm{N}$ no interior do citoplasma regulam o processo de passagem do processo de transcrição para replicação. Desta forma, se houver muita proteína produzida, o processo é parado e a replicação do genoma é iniciada. O primeiro passo na replicação é a síntese de cópias de polaridade positiva (anti-genoma) de todo o genoma viral. Para que estas sejam geradas, os sinais de transcrição representados por códons de parada e continuação de leitura são ignorados; a RNA polimerase reconhece a extremidade 3' do genoma e sintetiza uma cópia complementar ao mesmo, em todo seu comprimento. Estas cópias positivas servirão de molde para a síntese de novos genomas (de polaridade negativa) que irão fazer parte dos novos vírions a serem formados.

Durante a montagem, um complexo formado pelas proteínas $\mathrm{N}, \mathrm{P}$ e L promove a encapsidação dos novos genomas. A proteína $\mathrm{M}$ envolve a RNP; esse complexo vai para uma área da membrana plasmática (ou vesículas membranosas internas) e $\mathrm{M}$ inicia $\mathrm{o}$ "enovelamento" da partícula, conferindo-lhe o formato de "mola" que caracteriza a disposição helicoidal da RNP. A seguir, as partículas ligam-se à membrana celular, que dará origem ao envelope no qual foram inseridas moléculas da glicoproteína $\mathrm{G}$; tem início o brotamento, que irá liberar novos vírions. Esse processo não causa lise das células infectadas; em cultivos in vitro, as células infectadas podem permanecer por longos períodos viáveis e liberando novos vírions. Por outro lado, alerta para o papel do sistema imune do hospedeiro, que parece desempenhar função importante na evolução da infecção $[150,166]$.

\section{Variabilidade entre amostras de vírus}

Historicamente, o VR tem sido considerado um vírus bastante estável. Algumas das amostras de vírus vacinais ainda hoje utilizadas são derivadas do vírus isolado por Pasteur no final do século dezenove. Uma amostra de VR de Pasteur sofreu 3080 passagens em coelhos até 1953, evidenciando poucas alterações em sua patogenicidade [88]. Não obstante, ao longo das últimas décadas vem sendo acumuladas evidências de que essa estabilidade não é absoluta; isso é coerente com o caráter de quasispécie (ou seja, um conjunto heterogêneo de vírions representativo de determinada população), especialmente evidente nos vírus que tem RNA como material genético [101]. Os estudos que levaram ao desenvolvimento da vacina anti-rábica preparada em cérebro de camundongos lactentes [51], amplamente utilizada na América Latina, já apontavam para diferenças antigênicas significativas entre amostras de VR [37].

Nos anos 80, com a utilização de anticorpos monoclonais (AcMs) para o estudo de amostras do VR, a ocorrência de variantes antigênicas tornou-se bem mais evidente $[39,40,168]$. Aqueles estudos e muitos outros que os sucederam [12,34,38,47,74,105,120,129, 130,140] confirmaram que amostras de VR originárias de diferentes hospedeiros naturais apresentavam variantes com características antigênicas particulares.

A caracterização antigênica de variantes é usualmente realizada através de testes de imunofluorescência indireta, onde o vírus (multiplicado em camundongos ou cultivos celulares) é fixado em lâminas e colocado a reagir frente a painéis de AcMs preparados contra antígenos da proteína N. No Brasil, dois painéis de AcMs tem sido utilizados com essa finalidade. O primeiro deles é constituído por oito AcMs preparados contra diversas amostras do VR, fornecido pelo Centers for Disease Control and Prevention (CDC), Atlanta, USA, e preestabelecido pela OPAS para o estudo de amostras isoladas nas Américas [34,38, $47,100,140]$. Com esse painel foram identificadas no Brasil até o presente as variantes denominadas 2 (encontrada principalmente em cães, apresentando o perfil típico de amostras de raiva urbana), $\mathbf{3}$ (variante usualmente identificada em morcegos Desmodus rotundus), variante 4 (identificada em morcegos insetívoros Tadarida brasiliensis), variante $\mathbf{5}$ (relacionada a morcegos hematófagos na Venezuela, porém no Brasil isolada de uma "raposa" ou "cachorro-do-mato" (Cerdocyon thous) e variante 6, isolada de um morcego insetívoro Lasiurus cinereus, além de algumas amostras com perfis atípicos que não puderam ser enquadradas na classificação adotada, estas provavelmente outros exemplos do processo adaptativo [47].

O outro painel que tem sido utilizado é composto por $14 \mathrm{AcMs}$ anti-N dirigidos contra antígenos de diferentes lissavírus (Lagos bat, Mokola, Duvenhage e Danish bat) [74]. Esse painel, preparado por A. King 
no Central Veterinary Laboratory (hoje Central Veterinary Agency), Weybridge, Grã-Bretanha, tem sido utilizado no IPVDF para a caracterização de amostras de VR. O mesmo foi ampliado pela inclusão de outros dois AcMs preparados localmente contra antígenos da amostra CVS de VR [121,131]. Quatro AcMs deste painel permitiram a diferenciação entre variantes de morcegos hematófagos, morcegos não hematófagos e variantes de cães; um outro grupo foi evidenciado compreendendo uma amostra de cão, um isolado de um caso humano e uma amostra padrão do VR, denominada "PV" [12,121,131,151].

Mais recentemente, os estudos sobre variantes antigênicas têm sido complementados por análises genômicas que levaram à identificação de variantes genotípicas do VR. Face aos importantes reflexos que tais variantes - antigênicas ou genotípicas - têm sobre o conhecimento da biologia da infecção e suas interações com as espécies hospedeiras e o meio ambiente, estes estudos tem sido o foco da atenção de um grande número de pesquisadores [14,32,47,66,67,76,77, 126,132,144]. Estes estudos serão mais explorados mais adiante em outros capítulos desta sucinta revisão.

\section{Patogenia E Sinais CLínicos}

\section{Transmissão}

A maioria das infecções pelo vírus rábico se dá por transmissão percutânea, através da mordedura de animais infectados [59]. A transmissão por via aérea pode ocorrer raramente, mas não tem significância epidemiológica importante no ciclo da infecção. $\mathrm{O}$ contato com ferimentos abertos e membranas mucosas pode ocasionalmente levar à transmissão de raiva, assim como procedimentos médicos, como transplantes de córneas e outros órgãos. Recentemente foram relatados na Europa e EUA casos de raiva humana onde a infecção ocorreu através de transplantes de órgãos sólidos (rins, pulmões, figado e pâncreas) provenientes de doadores com encefalite de origem desconhecida $[58,71,82,148]$. Este fato salienta a necessidade da inclusão de testes específicos para o diagnóstico de raiva, particularmente em potenciais doadores com sinais de comprometimento neurológico.

\section{Período de incubação}

O período de incubação da raiva é muito variável após infecções naturais. Diversos fatores podem estar associados a um maior ou menor período de incubação, tais como a amostra de vírus envolvida, o local da mordedura (quanto mais próximo do sistema nervoso central, mais rápido o acesso do vírus ao mesmo), a carga viral presente na ocasião da agressão, a suscetibilidade da espécie exposta e imunidade do animal agredido. Geralmente, o período de incubação é de 2 a 12 semanas, porém períodos superiores á um ano já foram relatados [61,95]. Louis Pasteur, através de várias passagens do VR em coelhos, conseguiu "fixar" o período de incubação daquela amostra em cerca de sete dias. Isso deu origem ao termo "vírus fixo", que refere-se à amostras derivadas daquelas utilizadas por Pasteur e ainda hoje usadas como padrões e presentes na maioria dos laboratórios [88].

\section{Replicação no hospedeiro}

Uma vez inoculado no novo hospedeiro, o vírus pode replicar-se nas células musculares, próximas ao local da inoculação, antes de invadir o sistema nervoso central (SNC). Esta replicação representa um passo de multiplicação necessário à invasão do sistema nervoso [102]. Contudo, ocasionalmente, pode ocorrer a entrada direta do vírus no SNC, sem replicação prévia no músculo [134]. A seguir, o vírus é conduzido via terminações nervosas motoras, aos nervos periféricos, provavelmente pela combinação de fluxo axoplásmico retrógrado (provavelmente utilizando o sistema motor celular envolvendo a dineína), transmissão célula-célula via junções sinápticas e passagem direta do vírus através de conexões intercelulares e atinge o SNC [69,70,152].

Após a infecção do SNC, o vírus se dissemina via nervos periféricos de forma centrífuga para os tecidos não neuronais, distribuindo-se por todo o organismo. Antígenos virais já foram detectados em células da epiderme, folículos pilosos, retina, córnea, glândulas lacrimais, glândulas salivares, pulmões, músculo cardíaco, mucosa gástrica e intestinal, pâncreas, parênquima renal, glândulas adrenais, tecidos neuro-epiteliais dos ureteres, bexiga e uretra [27]. O vírus replica-se nas glândulas salivares; sua excreção através da saliva é o principal mecanismo de disseminação e perpetuação do mesmo na natureza [131].

Os sinais clínicos aparecem somente após o envolvimento do SNC. A morte é consequiente ao comprometimento de centros nervosos vitais.

É sabido já há bastante tempo que amostras do VR apresentam diferentes potenciais de neuroinvasividade. Amostras adaptadas a cultivos celulares e 
amostras de "vírus de rua" (como são chamadas amostras de vírus isoladas de cães) podem apresentar potenciais patogênicos diferentes. Algumas amostras isoladas de morcegos são menos neuroinvasivas do que as amostras de vírus de rua [43]. A glicoproteína $\mathrm{G}$ parece desempenhar o papel mais importante na determinação da neurovirulência, embora associada a outros fatores [43].

\section{Sinais clínicos}

A apresentação clínica da raiva é muito variada na grande maioria das espécies atingidas. As apresentações clássicas da doença são as formas paralítica e furiosa, as quais são consequientes à localização das lesões no SNC. O início do quadro, ou fase prodrômica, pode anteceder as manifestações mais típicas e revelar sinais pouco sugestivos, tais como alterações de comportamento, inapetência, apatia, depressão, inquietude e incoordenação motora. Após a fase prodrômica pode manifestar-se a fase furiosa, freqüentemente observada em caninos, onde o sinal mais marcante é a agressividade, embora possam ser também observados sinais de depressão, excitabilidade, mudanças de comportamento, insônia e, ocasionalmente, febre $[9,59,95]$. O animal não consegue deglutir; a salivação, em função dessa dificuldade, torna-se evidente. Pode ainda ser observado um aumento do limiar de sensibilidade a tranqüilizantes ou sedativos e, se anestesiados, os cães podem apresentar alucinações e convulsões no período pós-anestésico. Uma paralisia ascendente manifesta-se a partir dos membros inferiores.

Na forma paralítica da doença, pode não haver sinais prévios de agressividade. O maxilar inferior é o local onde a paralisia é mais notável. A boca permanece entreaberta e ocorre salivação. Igualmente, sobrevém a paralisia dos membros posteriores. O desfecho do quadro é fatal. Ocasionalmente, pode ocorrer morte súbita do animal, sem a manifestação de qualquer sinal clínico [95]. A morte se dá por paralisia dos músculos respiratórios.

A forma paralítica é mais comum em bovinos, consequiente a lesões na medula, tronco encefálico e cerebelo [113]. A paralisia aguda, progressiva, flácida, manifestando-se inicialmente pelos membros posteriores, é o sinal mais marcante. Podem ocorrer ainda sinais indicativos de comprometimento dos nervos lombares e sacrais, provocando constipação, tenesmo, parafimose em machos e gotejamento de urina $[59,86$,
95,113]. Em eqüinos, pode ser observada irritação no ponto de penetração do vírus, associada a grande excitação; a paralisia manifesta-se primeiro na faringe, esôfago e depois atinge os membros posteriores [59].

Em outras espécies, a raiva deve ser lembrada sempre que qualquer tipo de comportamento sugestivo de comprometimento neurológico, tais como morcegos encontrados em locais de circulação de humanos ou animais atropelados. Como tal, os mesmos devem ser manuseados somente por pessoas cientes desse tipo de risco, com cuidados para minimizar as chances de contaminação. Um excelente material sobre este e outros temas relacionados à raiva está disponível na home page do Instituto Pasteur [79,80].

\section{EPIDEMIOLOGIA}

A raiva está presente em todos os continentes, à exceção da Austrália e Antártica. Alguns países (Inglaterra, Irlanda, Japão e países escandinavos) obtiveram sucesso na erradicação da doença. A alta capacidade de adaptação do vírus, o qual pode adotar como reservatórios diferentes espécies, permite esta ampla distribuição. Até o presente, nas Américas, todas as amostras de vírus do gênero Lyssavirus isoladas pertencem ao genótipo 1, que compreende todas as amostras "clássicas" do VR [10,14,75,105]. Um único estudo reporta uma amostra de VR isolada no Brasil como pertencente ao genótipo 5 [56]. Entretanto, após esse registro, nenhuma outra amostra desse genótipo foi identificada.

A epidemiologia da raiva vem sendo examinada por outros ângulos em função da identificação de animais soropositivos em várias espécies, incluindo mangostas, morcegos hematófagos e insetívoros, guaxinins, gambás, raposas, hienas, chacais, cães selvagens e domésticos na Etiópia [2,40,44,47,90,97,114,122, 137,160]. Em particular em relação a morcegos, já em 1936 foi registrada a possibilidade de morcegos hematófagos tornarem-se portadores da infecção, mas em função dos métodos disponíveis à época, as evidências apresentadas deixaram margem a dúvidas [157, 158]. Não obstante, vírus infeccioso foi isolado repetidamente de cães assintomáticos na Etiópia e na Nigéria [1,47]. RNA viral foi detectado em hienas na África, sugerindo a ocorrência de mostras de baixa patogenicidade nesta espécie [42].

\section{Ciclos da raiva}

Na natureza, o VR é mantido por ciclos ocasionalmente inter-relacionados, denominados ciclos 
urbano e silvestre, aéreo e rural. Ciclo "urbano" referese à raiva em cães e gatos domésticos; ciclo aéreo refere-se à raiva em morcegos (sendo os demais ciclos denominados ciclos "terrestres"). Ciclo "rural" refere-se à raiva dos herbívoros, que envolve, principalmente bovinos e eqüinos e na qual o principal vetor é o morcego hematófago. O termo "silvestre" referese à raiva associada a espécies silvestres, sendo por vezes utilizado englobando o ciclo aéreo. Antes, porém, de abordar os ciclos da raiva propriamente ditos, para os objetivos desta revisão é importante a definição do termo de "hospedeiro natural" ou "reservatório natural", onde o vírus é capaz de manter-se sem a re-introdução do vírus a partir de outra espécie. Esta condição provavelmente depende de um balanço entre a adaptatividade da amostra viral e o tamanho da população hospedeira [114]. Os hospedeiros naturais são os principais vetores da infecção. As demais espécies são acidentalmente envolvidas e tornam-se hospedeiros finais da infecção, pois o ciclo é terminado no momento em que hospedeiro morre. Ocasionalmente, espécies de hospedeiros não naturais do vírus podem atuar como vetores da infecção [22,24,31,45,128].

\section{Ciclo urbano}

O ciclo urbano da raiva tem como hospedeiro natural o cão doméstico [59]. O caráter zoonótico da raiva é mais evidente neste ciclo em função da natureza da relação entre cães e humanos. Variantes do VR adaptadas a cães são detectadas em áreas onde a raiva urbana permanece endêmica [13]. Ocasionalmente, cães podem ser infectados por amostras de VR que tem outras espécies como hospedeiros naturais. Nesses casos, esses incidentes freqüentemente envolvem morcegos [22,24,26]. Essa possibilidade gera uma das grandes preocupações dos profissionais envolvidos em ações de controle desta zoonose: a possibilidade da re-introdução da raiva urbana em populações caninas a partir de vírus associado a outros ciclos da infecção. No entanto, ainda não foram determinadas as condições capazes de levar uma variante de morcegos (ou outra espécie) adaptar-se a caninos (ou outra espécie), de forma a ter nessa outra espécie um novo hospedeiro natural, embora isso certamente ocorra na natureza, como exemplificado pelos membros do gênero Lyssavirus [10].

\section{Ciclo aéreo}

No Brasil, das cerca de 140 espécies de morcegos identificadas, o VR já foi isolado de 31 espécies
[61]. Em ambientes urbanos, o VR têm sido identificado em diversas espécies de morcegos não hematófagos (Tadarida brasiliensis, Nyctinomops macrotis, Myotis Nigricans, Artibeus lituratus e Molossus molossus, entre outras) $[30,76,90,109,115,161]$. A presença de morcegos potencialmente contaminados com o vírus em áreas sinantrópicas representa um problema sério, especialmente para animais de estimação e seres humanos, constituindo-se em uma fonte de contaminação perigosa, particularmente pela possibilidade de passar insuspeita [61,78,79].

Em toda a América Latina, os morcegos hematófagos Desmodus rotundus são os principais hospedeiros do vírus na natureza no ciclo aéreo, ou ciclo silvestre aéreo, sendo os principais transmissores da infecção a bovinos e outros herbívoros (ciclo rural). Esse fato foi reportado pela primeira vez em bovinos há quase cem anos atrás no Estado de Santa Catarina [22]. O bovino é a fonte preferencial de alimento dos morcegos $D$. rotundus. Não obstante, podem atacar outras espécies na busca de alimento, inclusive humanos $[31,54,120,123,125,128,132,157,158]$. Há ainda as duas outras espécies de morcegos hematófagos conhecidas, Diphylla ecaudata e Diaemus youngi, as quais alimentam-se preferencialmente de sangue de aves, embora possam ocasionalmente buscar alimento em seres humanos [123]. Estas espécies podem ser contaminadas com o VR, mas sua participação na manutenção dos ciclos da infecção é irrelevante.

\section{Ciclo silvestre}

No ciclo silvestre terrestre, o vírus pode utilizar como reservatórios naturais diferentes espécies, as quais podem variar em função da fauna da região geográfica (Tabela 2). Além disso, variantes diferentes podem infectar uma mesma espécie em nichos geograficamente distintos. Assim, na Europa, o reservatório natural do vírus em seu ciclo silvestre é a raposa vermelha (Vulpes vulpes); na América do Norte, além das raposas, gambás (Mephitis mephitis) e guaxinins (Procyon sp.) são também hospedeiros naturais do vírus. No Brasil, recentemente, a raposa cinzenta (Dusicyon vetulus) foi igualmente demonstrada ser hospedeira natural de uma variante do vírus [14]. O VR foi também já identificado em jaritatacas (Conepatus sp), guaxinins (Procyon sp.) e sagüis (Calithrix $s p$.) e diversas outras espécies de morcegos não hematófagos e canídeos selvagens. Saliente-se que os sagüisde-tufo-branco (Calithrix jaccus) no Nordeste são ado- 
Tabela 2. Principais vetores da raiva silvestre e sua distribuição geográfica*.

\begin{tabular}{ll}
\hline Região geográfica & \multicolumn{1}{c}{ Vetores } \\
\hline Europa & Raposa vermelha (Vulpes vulpes); \\
América do Norte & Coiote (Canis latrans), texugo (Meles meles), guaxinim (Procyon lotor), gambá (Mephitis mephitis) \\
América Latina & $\begin{array}{l}\text { Morcego hematófago (Desmodus rotundus) } \\
\text { Raposa (Dusicyon vetulus), jaritataca (Conepatus sp.), guaxinim (Procyon sp.), sagüis } \\
\text { (Calithrix sp.) }{ }^{* *} \text { e diversas outras espécies de morcegos não hematófagos e canídeos selvagens. }\end{array}$ \\
\hline "Fontes: $113 ; 71 ; 156 ; 45 ; 107 ; 98 ; 14,61 .{ }^{* *}$ adotados como animais de estimação [46,98].
\end{tabular}

tados como animais de estimação, não devendo ser considerados animais estritamente silvestre. Estes sagüis são hospedeiros naturais de uma variante do VR [45,100], tendo sido responsáveis por sete casos de raiva humana registrados no período 1997-2006 [136].

\section{SITUAÇÃo DA RAIVA NO BRASIL}

\section{Raiva urbana}

A raiva no Brasil apresenta níveis distintos de endemicidade nas diferentes regiões do País. $\mathrm{Na}$ região Sul, a raiva urbana está controlada [49]. Os últimos casos em humanos nos Estados do Rio Grande do Sul e Santa Catarina ocorreram em 1981 [19,62]. No Paraná, o último caso humano foi registrado em 1987 [99]. Apesar disso, em 2001 ocorreu no Rio Grande do Sul um caso em felino cuja fonte de infecção foi uma variante de VR de origem de morcegos não hematófagos [129]. Em 2007 ocorreu a contaminação de um cão com uma variante de morcegos usualmente detectada em morcegos insetívoros [64]. Assim, apesar de episódios isolados de contaminação com vírus de outros hospedeiros naturais, as variantes do VR que tem como hospedeiro natural o cão não tem mais sido detectadas em populações caninas na região Sul.

As demais regiões do País ainda apresentam casos de raiva urbana. Não obstante, ao examinar os casos notificados no Brasil no decênio 1997-2006, observa-se que tem havido um decréscimo significativo e continuado de casos em caninos e felinos (Tabela 3). Até 2003, os cães eram os principais vetores da raiva para humanos no País. A partir daquele ano, os casos em humanos causados por cães foram suplantados pelas infecções associadas a morcegos hematófagos (Tabela 4).

\section{Raiva em morcegos e animais silvestres}

A notificação dos casos de raiva em morcegos aumentou significativamente nos últimos anos do período 1997-2006 (Tabela 3). Igualmente aumentaram os registros de casos em animais silvestres nesse período. Particularmente preocupantes são os registros de casos em morcegos não hematófagos, pois sua adaptação ao ambiente urbano pode dar margem a infecções humanas. Apesar disso, até o presente ainda não foi registrado no País nenhum caso de raiva hu-

\begin{tabular}{lcccccccccc}
\multicolumn{1}{l}{ Tabela 3. Casos notificados de raiva em animais no Brasil no decênio } & 1997-2006 (não computados os registros de raiva bovina). \\
\hline & 1997 & 1998 & 1999 & 2000 & 2001 & 2002 & 2003 & 2004 & 2005 & 2006 \\
\hline Cão & 945 & 1745 & 970 & 761 & 657 & 617 & 289 & 104 & 93 & 67 \\
Gato & 65 & 165 & 93 & 69 & 27 & 67 & 21 & 10 & 10 & 7 \\
Morcego hematófago & - & - & 4 & 8 & 72 & 12 & 11 & 19 & 60 & 50 \\
Morcego não hematófago & - & - & - & 20 & 27 & 2 & 8 & 30 & 136 & 25 \\
Morcegos não identificados & - & - & 6 & 2 & 2 & 55 & 94 & 38 & - & - \\
Animais silvestres & 36 & 36 & 37 & 61 & 144 & 89 & 155 & 124 & 251 & 208 \\
\hline Adaptado de [133,136]. & & & & & & & & & &
\end{tabular}




\begin{tabular}{|c|c|c|c|c|c|c|c|c|c|c|c|}
\hline Espécie transmissora & 1997 & 1998 & 1999 & 2000 & 2001 & 2002 & 2003 & 2004 & 2005 & 2006 & Total \\
\hline Bovino & - & - & - & - & - & - & - & 1 & - & 1 & 2 \\
\hline Cão & 17 & 19 & 21 & 24 & 18 & 6 & 14 & 5 & 1 & 6 & 131 \\
\hline Gato & 3 & 2 & - & 1 & 1 & - & - & 1 & - & - & 8 \\
\hline Morcego hematófago & - & - & - & - & - & 3 & 3 & 22 & 42 & 2 & 72 \\
\hline Morcego não hematófago & - & - & - & - & - & - & - & - & - & - & - \\
\hline Morcego sp. indeterminada & - & 4 & 2 & - & - & - & - & - & - & - & 6 \\
\hline Guaxinim (Procyon sp.) & 1 & - & - & - & - & - & - & - & - & - & 1 \\
\hline Macaco & - & 3 & - & 1 & 2 & - & - & - & 1 & 1 & 7 \\
\hline Total & 21 & 27 & 23 & 26 & 21 & 9 & 17 & 27 & 44 & 9 & 227 \\
\hline
\end{tabular}

mana transmitida por morcegos não hematófagos (Tabela 4).

\section{Raiva em humanos}

Os casos de raiva em humanos registrados no decênio 1997-2006, bem como as espécies animais envolvidas na transmissão, são apresentados na Tabela 4. Observa-se no período uma significativa redução dos casos de raiva urbana provocados por cães e gatos. Até 2003, os cães foram responsáveis pela transmissão de 119 (84\%) de 141 casos humanos. Infelizmente, em 2004 e 2005 os casos notificados de raiva humana transmitida por morcegos hematófagos apresentaram um incremento importante em decorrência de surtos ocorridos na região Amazônica tornando-se os principais transmissores da infecção a humanos [31]. Como consequiência, tivemos em 2005 o maior número de casos de raiva humana registrados no decênio [133]. Dos 80 casos notificados no triênio 20042006, morcegos hematófagos foram implicados em $66(82,5 \%)$ ao passo que cães estiveram envolvidos em 12 episódios (15\%).

\section{Raiva dos herbívoros}

Além dos problemas causados à saúde pública, a raiva traz sérios prejuízos econômicos à pecuária nacional, tendo sido responsável nos últimos dez anos por mais de 23000 casos notificados em herbívoros. Saliente-se que a sub-notificação de casos de raiva em herbívoros é uma realidade, de forma que é praticamente impossível determinar o real número de perdas associadas à doença. Os casos notificados de raiva dos herbívoros no Brasil no decênio 1997-2006, reportados aos órgãos oficiais são apresentados na Tabela 5 [90,136]. Na região sudeste ocorreu um aumento nos casos de raiva notificados em herbívoros; entretanto, é possível que esses dados reflitam uma maior eficácia na notificação. Na região Nordeste, os casos em ovinos e caprinos representam uma parcela significativa dos casos de raiva em herbívoros [55].

\section{Diagnóstico}

\section{Diagnóstico virológico}

O tecido de eleição para o diagnóstico de raiva é o encéfalo dos animais suspeitos. Em eqüinos, além do encéfalo, recomenda-se enviar ao laboratório fragmentos de medula. Podem igualmente ser remetidos ao laboratório fragmentos de tecidos encefálicos, devendo ser incluídas porções do cerebelo, córtex e circunvoluções do hipocampo (ou cornos de Amon). Animais pequenos (p.ex. morcegos, gambás, sagüis) devem ser remetidos inteiros ao laboratório [61]. $\mathrm{Na}$ impossibilidade de abrir a caixa encefálica com segurança, a cabeça do animal pode ser igualmente remetida ao laboratório. As amostras deverão ser remetidas sob refrigeração. Em locais onde não há condições de manter o material refrigerado, recomenda-se a imersão de fragmentos de tecido em Líquido de Vallée (glicerina 50\% tamponada com tampão fosfato: $\mathrm{KH}_{2} \mathrm{PO}_{4}$ $1,80 \mathrm{~g} ; \mathrm{K}_{2} \mathrm{H}_{2} \mathrm{PO}_{4} 2,30 \mathrm{~g}$; glicerina neutra, 50\%; $\mathrm{H}_{2} \mathrm{O}$ q.s.p. $1000 \mathrm{ml}$; pH 7,4-7,8). Nesse líquido, o vírus se mantém detectável por vários dias. Cuidados na re- 


\begin{tabular}{|c|c|c|c|c|c|c|c|c|c|c|c|}
\hline Regiões & 1997 & 1998 & 1999 & 2000 & 2001 & 2002 & 2003 & 2004 & 2005 & 2006 & Total \\
\hline Norte & 68 & 74 & 61 & 2676 & 235 & 346 & 662 & 185 & 138 & $\mathrm{nd}^{*}$ & 4445 \\
\hline Nordeste & 406 & 269 & 374 & 302 & 198 & 226 & 226 & 257 & 309 & nd & 2567 \\
\hline Sul & 48 & 81 & 52 & 77 & 60 & 193 & 140 & 147 & 158 & nd & 956 \\
\hline Sudeste & 2335 & 2360 & 2666 & 2835 & 1324 & 1201 & 863 & 512 & 500 & nd & 14596 \\
\hline Centro-Oeste & 94 & 240 & 254 & 409 & 697 & 824 & 761 & 725 & 805 & nd & 4810 \\
\hline Total & 2951 & 3024 & 3407 & 6299 & 2514 & 2790 & 2652 & 1826 & 1911 & ** & 27374 \\
\hline
\end{tabular}

moção do encéfalo, como o uso de equipamentos de proteção individual, são importantes para evitar acidentes e inoculações acidentais com material infectado.

O primeiro método laboratorial rápido proposto para o diagnóstico de raiva foi a detecção de corpúsculos de Negri, método este descrito por Adelchi Negri há mais de um século [90,104]. Negri acreditava que estas inclusões eram formas de um protozoário que ele julgava ser o causador da raiva. Na verdade, são agregados de nucleocapsídeos que acumulam-se no interior do citoplasma das células infectadas. Tais inclusões são patognomônicas para raiva, porém, outras inclusões podem levar à interpretações equívocas [85]. A sensibilidade das provas baseadas na identificação destes corpúsculos é baixa, permitindo a detecção de cerca de aproximadamente $40 \%$ a $85 \%$ dos casos positivos. Em certas espécies (p. ex. eqüinos) a detecção de corpúsculos de Negri pode apresentar menor sensibilidade [63].

Em 1958, a técnica de imunofluorescência direta (IFD) foi adaptada para o diagnóstico de raiva [54]. Esta passou a ser amplamente utilizada devido a sua alta sensibilidade e especificidade. A IFD baseiase na detecção do vírus em esfregaços de tecido com anticorpos específicos conjugados a uma substância fluorescente (isotiocianato de fluoresceína) [35]. Em um laboratório com equipamento e pessoal adequadamente treinado, a IFD chega a atingir sensibilidade e especificidade próximas a $100 \%$. Em função disso, a IFD permanece como a técnica de eleição para o diagnóstico rápido de raiva. Usualmente, a IFD é acompanhada de um teste de confirmação biológica, como a inoculação em camundongos lactentes. Buscando diminuir as necessidades de inoculação em animais de experimentação, por razões tanto humanitárias como de custo, há uma tendência a substituir a inoculação de camundongos pela inoculação de cultivos celulares [163].

Mais recentemente, outra eficaz técnica utilizada na detecção de antígenos virais em células infectadas foi a citometria de fluxo [17]. Entretanto, sua aplicação ainda é limitada em função da indisponibilidade do equipamento na maioria dos laboratórios de diagnóstico.

Técnicas baseadas em métodos moleculares vêm sendo largamente aplicadas ao diagnóstico e caracterização do VR [5,24,56,67,73,122,125-128]. A maioria destas técnicas baseia-se na transcrição reversa de determinado segmento do genoma viral, seguida de amplificação pela reação da polimerase em cadeia (PCR) ou suas variações $[57,73,103,105,144,146]$. Os fragmentos gerados podem ter sua especificidade confirmada com a aplicação de sondas [26]. Na maioria dos estudos, os amplicons obtidos são submetidos a cortes com enzimas de restrição, clonagem ou seqüenciamento, permitindo as análises filogenéticas que vem redefinindo o conhecimento sobre as interações do vírus com seus hospedeiros [18,19,25,33,102,122,145,157].

\section{Diagnóstico sorológico}

O diagnóstico sorológico não é rotineiramente empregado para diagnóstico de casos suspeitos de raiva em animais; nestes casos, o exame post mortem do sistema nervoso em busca de antígenos é absolutamente eficaz. Em humanos, onde o diagnóstico ante mortem é relevante e o acesso ao SNC não está facilmente disponível, a avaliação de anticorpos desempenha um importante papel no estabelecimento do 
diagnóstico. Nestes casos, a elevação de títulos de anticorpos no líquido céfalo-raquidiano é considerada diagnóstica em casos suspeitos. Não obstante, os testes sorológicos para raiva são utilizados com vários outros objetivos. Freqüentemente têm sido empregados para avaliar a capacidade imunogênica de vacinas antirábicas, bem como para avaliar o status sorológico de populações submetidas à vacinação. Os testes sorológicos têm também sido usados para comprovar o contato de populações não vacinadas com o vírus, evidenciando que o VR pode ocasionalmente circularem determinados hospedeiros sem necessariamente causar morte imediata - seja por induzir infecções com longo período de incubação, seja pela indução do estado de portador (ou seja, um indivíduo capaz de transmitir a infecção a terceiros, porém assintomático) - o que é ainda tema de debate entre pesquisadores.

A detecção de anticorpos contra o VR é realizada usualmente através da técnica de soro-neutralização (SN) $[21,45,116,118,119,162]$. A SN baseia-se na mistura de uma quantidade conhecida de vírus com diluições do soro a testar; se o soro possuir anticorpos específicos, o vírus será neutralizado. Para evidenciar a multiplicação viral, utilizam-se tradicionalmente camundongos como sistema indicador, sistema este desenvolvido em 1935 e, não obstante, ainda bastante utilizado [162]. Com a possibilidade do cultivo do VR in vitro, a aplicação da SN utilizando cultivos celulares como indicadores têm facilitado o diagnóstico sorológico da raiva, diminuindo custos e o tempo necessário para a obtenção dos resultados, além de evitar o uso de animais de laboratório $[15,21,163]$.

Outra prova sorológica similar bastante utilizada é a denominada "teste rápido de inibição de focos fluorescentes" (RFFIT:"rapid fluorescent focus inhibition test"). Nesta prova, a neutralização do vírus pelo soro é revelada pelo bloqueio da reação do conjugado FITC/soro anti-rábico [114,139,142].

Um outro teste sorológico, a inibição da imunoperoxidase ou IIPX [11], não visa à detecção de anticorpos neutralizantes, mas quaisquer anticorpos capazes de reconhecerem antígenos virais em células infectadas. A IIPX vem sendo comparativamente avaliada com a SN sobre um número significativo de amostras de soros.

Além destas, ensaios imunoenzimáticos (ELISA) também tem sido desenvolvidos para a detecção de anticorpos contra a raiva $[6,42,107]$. Entretanto, estes testes freqüentemente apresentam problemas de baixa especificidade, necessitando laboriosas purificações dos antígenos utilizados [107]. Elmgren \& Wandeler [41] desenvolveram um teste de ELISA competitivo que utiliza antígenos parcialmente purificados que pode ser usado para a detecção de anticorpos em várias espécies animais. No Brasil, Piza et al. [111] avaliaram um teste de ELISA para a deteç̧ão de anticorpos em pessoas vacinadas. Em outro estudo de pesquisadores brasileiros, avaliaram a citometria de fluxo para a detecção de anticorpos contra o VR [16].

\section{ViI. Prevenção e Controle}

A prevenção da raiva baseia-se na vacinação e no controle de vetores. As principais medidas de controle do ciclo urbano da raiva tem sido a vacinação de caninos e felinos e a captura e eliminação de cães errantes [133]. Como citado acima, o número de casos de raiva canina no País tem diminuído significativamente, o que aumenta a importância das ações de vigilância epidemiológica visando prevenir a reintrodução da doença. $\mathrm{O}$ controle de focos com a aplicação de vacinação em massa, nas áreas focal e perifocal, com vacinas inativadas, são as medidas recomendadas [13].

A raiva dos herbívoros é controlada pela vacinação de animais em áreas endêmicas e pelo controle das populações de morcegos hematófagos. Para a vacinação, a tendência é a utilização de vacinas inativadas, que representam atualmente $95 \%$ das vacinas para bovinos comercializadas no Brasil (estimativa de mais de 100 milhões de doses/ano) [139]. Para o controle das populações de morcegos hematófagos são geralmente empregados métodos baseados na aplicação de uma pasta contendo uma substância anti-coagulante, a qual é aplicada topicamente em morcegos capturados e posteriormente liberados para retornar a sua colônia. Como os morcegos tem o hábito de limparem-se mutuamente, o anti-coagulante aplicado deverá levar à eliminação de vários indivíduos na colônia $[3,53]$. Outros métodos envolvendo a aplicação de anticoagulantes a bovinos em feridas de mordeduras de morcegos, a administração destas substâncias por via intra-muscular ou intra-ruminal pode ser empregados, mas não são rotineiramente utilizados [3]. 
O controle da raiva em quirópteros em regiões sinantrópicas tem se tornado alvo da preocupação dos órgãos de vigilância sanitária. As estratégias propostas para o combate à raiva em quirópteros urbanos foram recentemente discutidas no II Seminário de Manejo de Quirópteros em Áreas Urbanas, em São Paulo $[61,79,80]$. Dentre as várias propostas, selecionamos algumas fundamentais, as quais são aqui mencionadas: 1) interação entre órgãos de vigilância e de controle ambiental; 2) estímulo à pesquisa em quirópteros; 3 ) estímulo à capacitação para o trabalho com morcegos; 4) estímulo à formação de uma rede de laboratórios regionais habilitados à prática com quirópteros; 5) incremento de estudos sobre a quiropterofauna e 6) aumentar o nível de conscientização da população sobre o problema $[79,80]$.

Agradecimentos. Os trabalhos sobre raiva têm sido apoiados pelo Governo do Estado do Rio Grande do Sul, FAPERGS, CNPq e FINEP. HBCRB é doutoranda do Programa de Pós-graduação em Ciências Veterinárias da Faculdade de Veterinária da UFRGS. PMR é bolsista pesquisador 1A do CNPq.

\section{REFERÊNCIAS}

1 Aghomo H.O. \& Rupprecht C.E. 1990. Further studies on rabies virus isolated from healthy dogs in Nigeria. Veterinary Microbiology. 22: 17-22

2 Aghomo H.O., Ako Nai A.K. \& Oduye O.O. 1990. Detection of rabies virus antibodies in fruit bats (Eidolon helvum) from Nigeria. Journal of Wildlife Diseases. 26: 258-261.

3 Alencar O.A., Freitas C.E.A., P.M., Rodrigues I. \& Severo J.E.V. 1986. Avaliação do comportamento de produtos a base de Warfarina (3-alfa acetonilbenzil)-4-hidroxicumarina) no combate aos morcegos hematófagos por aplicação via intramuscular em bovinos. Arquivo Brasileiro de Medicina Veterinária e Zootecnia. 38: 43-50.

4 Amengual B., Whitby J.E., King A., Cobo J.S. \& Bourhy H. 1997. Evolution of european bat lyssavirus. Journal of General Virology. 78: 2319-2328.

5 Arai Y.T., Yamada K., Kameoka Y., Horimoto T., Yamamoto K., Yabe S., Nakayama M. \& Tashiro M. 1997. Nucleoprotein gene analysis of fixed and street rabies virus variants using RT-PCR. Archives of Virology. 142: 1787-1796.

6 Atanasiu P., Savy V. \& Perrin P. 1977. Rapid detection of rabies antibodies by immunoenzymatic assay. Annales de Microbiologie. 128: 489-498.

7 Banerjee A.K. 1987. Transcription and replication of rhabdoviruses. Microbiology Reviews. 52: 66-87.

8 Botvinkin A.D., Poleschuk E.M., Kuzmin I.V., Borisova T.I., Gazarian S.V., Yager P. \& Rupprecht C.E. 2003. Novel lyssavirus isolated from bat in Russia. Emerging Infectious Diseases. 9: 1623-1625.

9 Baer G.M. \& Lentz T.L. 1991. Rabies pathogenesis to the central nervous system. In: Baer G.M. (Ed.) The Natural History of Rabies. 2nd edn. Boca Raton: RCR Press, pp.105-120.

10 Badrane H. \& Tordo N. 2001. Host switching in lyssavirus history from the chiroptera to the carnivora orders. Journal of Virology. 75: 8096-8104.

11 Batista H.B.C.R., Schmidt E., Reis F.K., Teixeira T.F., Maletich D., FrancoA.C., Rosa J.C.A.\& Roehe P.M. 2006. Development of an immunoperoxidase inhibition assay (IIA) for rabies antibody detection. XVII Reunião Internacional de Raiva nas Américas. p.156.

12 Batista H.B.C.R., Schmidt E., Teixeira T.F., Schaefer R. \& Roehe P.M. 2007. Caracterização antigênica de amostras do vírus da raiva isoladas nas regiões Norte e Centro Oeste do Brasil com anticorpos monoclonais anti-lissavírus. Arquivo Brasileiro de Medicina Veterinária e Zootecnia (aceito para publicação).

13 Belotto A., Leanes L.F., Schneider M.C., Tamayo H. \& Correa E. 2005. Overview of rabies in the Americas. Virus Research. 111: 5-12.

14 Bernardi F., Nadin-Davis S.A., Wandeler A.I.,Armstrong J., Gomes A.A.B., Lima F.S., Nogueira F.R.B. \& Ito F.H. 2005. Antigenic and genetic characterization of rabies viruses isolated from domestic and wild animals of Brazil identifies the hoary fox as a rabies reservoir. Journal of General Virology. 86: 3153-3162.

15 Bordignon J., Piza A.T., Alvarez-Silva M., Caporale G.M., Carrieri M.L., Kotait I. \& Zanetti C.R. 2001. Isolation and replication of rabies virus in C6 rat glioma cells (clone CCL-107). Biologicals. 29: 67-73.

16 Bordignon J., Comin F., Ferreira S.C.P., Caporale G.M.M., Lima Filho J.H.C. \& Zanetti C.R. 2002. Calculating rabies virus neutralizing antibodies titres by flow cytometry. Revista do Instituto de Medicina Tropical de São Paulo. 44: 151-154.

17 Bordignon J., Pires Ferreira S.C., Medeiros Caporale G.M., Carrieri M.L., Kotait I., Lima H.C. \& Zanetti C.R. 2002. Flow cytometry assay for intracellular rabies virus detection. Journal of Virological Methods.105: 181-186. 
18 Bordignon J., Brasil-dos-Anjos G., Bueno C.R., Salvatiera-Oporto J., Dávila A.M. R., Grisard E.C. \& Zanetti C.R. 2005. Detection and characterization of rabies virus in Southern Brazil by PCR amplification and sequencing of the nucleoprotein gene. Archives of Virology. 150: 695-708.

19 Bordignon J., Grisard E.C. \& Zanetti C.R. 2005. Molecular detection and characterization of rabies virus in Brazil: new approaches for epidemiology and surveillance. Virus Reviews and Research. 10: 14-22.

20 Bourhy H., Kissi B. \& Tordo N. 1993. Taxonomy and evolutionary studies on lyssavirues with special reference to Africa. Onderstepoort Journal of Veterinary Research. 60: 277-282.

21 Cardoso T.C., Silva L.H.Q., Albas A., Ferreira H.L. \& Perri S.H.V. 2004. Rabies neutralizing antibody detection by indirect immunoperoxidase serum neutralization assay performed on chicken embryo related cell line. Memórias do Instituto Oswaldo Cruz. 99: 531-534.

22 Carini A. 1911. Sur une grande epizootie de rage. Annales de l'Institut Pasteur. 25 : 843-846.

23 Carnieli P.J., Brandão P.E., Castilho J.G., Bueno C.R., Carrieri M.L., Oliveira R. N., Zanetti C.R. \& Kotait I. 2005. Phylogeny of a rabies virus identified in a cat closely related to vampire bat rabies based on the nucleoprotein gene. Virus Reviews and Research. 10: 50-54.

24 Carnieli P., Brandão P.E., Carrieri M.L., Castilho J.G., Macedo C.I., Lindenberg M.M., Rangel N., Carvalho R.C., Carvalho V.A., Montebelo L., Wada M. \& Kotait I. 2006. Molecular epidemiology of rabies virus strains isolated from wild canids in Northeastern Brazil. Virus Research. 120: 113-120.

25 Carnieli Jr. P., Ventura A.M. \& Durigon E.L. 2006. Digoxigenin-labeled probe for rabies virus nucleoprotein gene detection. Revista da Sociedade Brasileira de Medicina Tropical. 39: 159-162

26 Carrieri M.L., Favoretto S.R., Carnielli Jr. P., Peixoto Z.M.P., Achkar S., Paiva J.P.R.C. \& Kotait I. 2001. Canine and feline rabies in the Espírito Santo do Pinhal City, São Paulo, transmitted by bats. Virus Reviews and Research. 6: 176.

27 Charlton K.M. 1988. The pathogenesis of rabies. In: Rabies. Campbell J.B \& Charlton K.M. (Eds.). Boston: Kluwer Academic Publishers, pp.101-150.

28 Coll J.M. 1995. The glycoprotein G of rhabdoviruses. Archives of Virology. 140: 827-851.

29 Cox J.H., Dietzschold B. \& Schneider L.G. 1977. Rabies virus glycoprotein. II. Biological and serological characterization. Infection and Immunity. 16: 754-759.

30 Cunha E.M.S., Lara M.C., Nassar A.F., Sodré M.M. \& Amaral L.F. 2005. Isolation of rabies virus in Artibeus fimbriatus bat in state of Sao Paulo. Revista de Saúde Pública. 39: 683-684.

31 Da Rosa E.S., Kotait I., Barbosa T.F., Carrieri M.L., Brandão P.E., Pinheiro A.S., Begot A.L., Wada M.Y., De Oliveira R.C., Grisard E.C., Ferreira, M., Lima R.J., Montebello L., Medeiros D.B., Souza R.C., Bensabath G., Carmo E.H. \& Vasconcelos P.F. 2006. Bat-transmitted human rabies outbreaks, Brazilian Amazon. Emerging Infectious Diseases. 12: 1197-1202.

32 David D., Hughes G.J., Yakobson B.A., Davidson I., Un H., Aylan O., Kuzmin I.V. \& Rupprecht C.E. 2007. Identification of novel canine rabies virus clades in the Middle East and North Africa. Journal of General Virology. 88: 967-980.

33 Davies M.C., Englert M.E., Sharpless G.R. \& Cabasso V.J. 1963. The electron microscopy of rabies virus in cultures of chicken embryo tissues. Virology. 21: 642-651.

34 Delpietro H.A., Gury-Dhomen F., Larghi O. P., Mena-Segura C. \& Abramo L. 1997. Monoclonal antibody characterization of rabies virus strains isolated in the River Plate Basin. Zentrablatt fur Veterinarmedizin B. 44: 477-483.

35 Dean D.J., Abelseth M.K. \& Atanasiu P. 1996. The fluorescent antibody test. In: Laboratory techniques in rabies. Meslin F.X., Kaplan M.M., Koprowski (Eds). 4th edn. Geneva: World Health Organization, pp.88-95.

36 Diaz A.M.O., Dellapiane N. \& Palomo L.F. 1989. Vacuna antirrábica de cerebro de raton lactante: Composición antigénica y capacidad inmunógena. Boletin de la Oficina Sanitaria Panamericana. 107: 185-195.

37 Diaz A. M., Papo S., Rodriguez A. \& Smith J. S. 1994. Antigenic analysis of rabies-virus isolates from Latin América and Caribbean. Zentralbatt fur Veterinarmedizin B 41: 153-160.

38 Dietzschold B., Wunner W.H., Wiktor T.J., Lopes A.D., Lafon M., Smith C.L. \& Koprowski H. 1983. Characterization of an antigenic determinant of the glycoprotein that correlates with the pathogenicity of rabies virus. Proceedings of the National Academy of Sciences, USA. 80: 70-74.

39 Dietzschold B., Lafon M., Wang H., Otvos L. Jr., Celis E., Wunner W.H. \& Koprowski H. 1987. Localization and immunological characterization of antigenic domains of the rabies virus internal N and NS proteins. Virus Research. 8: $103-125$. 
40 East M.L., Hofer H., Cox J.H., Wulle U., Wiik H. \& Pitra C. 2001. Regular exposure to rabies virus and lack of symptomatic disease in Serengeti spotted hyenas. Proceedings of the National Academy of Sciences USA. 98: 15026-15031.

41 Elmgren L.D. \& Wandeler A.I. 1996. Competitive ELISA for the detection of rabies virus-neutralizing antibodies. In: Laboratory Techniques in Rabies. Meslin F.X., Kaplan M.M. \& Koprowski H. (Eds). 4th edn. Geneva: World Health Organization, pp.200-208.

42 Everard C.O., Baer G.M., Alls M.E. \& Moore S.A. 1981. Rabies serum neutralizing antibody in mongooses from Grenada. Transactions of the Royal Society of Tropical Medicine and Hygiene. 75: 654-666.

43 Faber M., Pulmanausahakul R., Nagao K., Prosniak M., RiceA.B., Koprowski H., Schnell M.J. \& Dietzschold B. 2004. Identification of viral genomic elements responsible for rabies virus neuroinvasiveness. Proceedings of the National Academy of Sciences USA. 101: 16328-16332.

44 Doc. Eletrônico (internet) Favoretto S. 1998. Estudo das amostras isoladas em morcegos. In: Manual Técnico do Instituto Pasteur. (Kotait I., org.) número 7 - Manejo de quirópteros em áreas urbanas. pp.32-34. Instituto Pasteur São Paulo. 45p. Disponível em: http://www.pasteur.saude.sp.gov.br/informacoes/informacoes_publicacoes.htm Acessado em 22/04/2007.

45 Favoretto S.R., De Mattos C.C., Morais N.B., Araujo F.A.A. \& De Mattos C.A. 2001. Rabies in marmosets (Callithrix jacchus), Ceará-Brazil. Emerging Infectious Diseases. 7: 1062-1065.

46 Favoretto S.R., Carrieri M.L., Cunha E.M.S.,Aguiar E.A.C., Silva L.H.Q., Sodré M.M., Souza M.C.A.M. \& Kotait I. 2002. Antigenic typing of brazilian rabies virus samples isolated from animals and humans, 1989-2000. Revista do Instituto de Medicina Tropical de São Paulo. 44: 91-95.

47 Fekadu M. 1972. Atypical rabies in dogs in Ethiopia. Ethiopian Medical Journal. 10: 79-86.

48 Fuenzalida E. \& Palacios R. 1955. Un método mejorado para la preparación de la vacuna antirrábica. Boletín del Instituto de Bacteriología. 8: 3-10.

49 Doc Eletrônico (internet) FUNASA-Fundação Nacional de Saúde. 2004. 100 anos de Saúde Pública. A Visão da FUNASA. Disponível em http://www.funasa.gov.br/Web\%20Funasa/pub/pdf/livro_100-anos.pdf. Acessado em 14/05/2007.

50 Gastka M., Horvath J. \& Lentz T.L. 1996. Rabies virus binding to the nicotinic acetylcholine receptor alpha subunit demonstrated by virus overlay protein binding assay. Journal of General Virology. 77: 2437-2440.

51 Gold A.R., Hyatt A.D., Lunt, R., Kattenbelt J.A., Hengstberger S. \& Blacksell S.D. 1998. Characterization of a novel lyssavirus isolated from pteropid bats in Australia. Virus Research. 54: 165-187.

52 Goldwasser R.A. \& Kissling R.E. 1958. Fluorescent antibody staining of street and fixed rabies virus antigens. Proceedings of the Society for Experimental Biology and Medicine. 98: 219-223.

53 Gomes M.N., Uieda W. \& Latorre M.R.D.O. 2006. Influência do sexo de indivíduos da mesma colônia no controle químico das populações do morcego hematófago Desmodus rotundus (Phyllostomidae) no estado de São Paulo. Pesquisa Veterinária Brasileira. 26: 38-43.

54 Gonçalves M.A.S., Neto R.S. \& Brazil T.K. 2002. Outbreak of aggressions and transmission of rabies in human beings by vampire bats in northeastern Brazil. Revista Sociedade Brasileira de Medicina Tropical. 35: 461-464.

55 Guedes K.M.R., Riet-Correa F., Dantas A.F.M., Simões S.V.D., Miranda Neto E.G., Nobre V.M.T. \& Medeiros R.M.T. 2007. Doenças do sistema nervoso central em caprinos e ovinos no semi-árido. Pesquisa Veterinária Brasileira 27: 29-38.

56 Heaton P.R., Johnstone P., McElhinney L.M., Cowley R., O’Sullivan E. \& Whitby J.E. 1997. Heminested PCR Assay for Detection of Six Genotypes of Rabies and Rabies-Related Viruses. Journal of Clinical Microbiology. 35: $2762-2766$.

57 Heinemann M.B., Matioli F.M.F., Cortez A., Soares R.M., Sakamoto S.M., Bernardi F., Ito F.H., Madeira A.M.B.N. \& Richtzenhain L.J. 2002. Genealogical analyses of rabies virus strains from Brazil based on $\mathrm{N}$ gene alleles. Epidemiology and Infection. 128: 503-511.

58 Hellenbrand W., Meyer C., Rasch G., Steffens I. \& AmmonA. 2005. Cases of rabies in Germany following organ transplantation. Euro Surveill. 10: 213-216.

59 Hipólito O. 1948. Raiva. In: Doenças dos Animais Transmissíveis ao Homem. Serviço de Informação Agrícola, Ministério da Agricultura, Rio de Janeiro. 90: 31-37.

60 Doc Eletrônico (internet) ICTVdB - The Universal Virus Database, version 4. Disponível em http://www.ncbi.nlm.nih.gov/ ICTVdb/ICTVdB/. Acessado em 23/02/2007.

61 Doc Eletrônico (internet) Instituto Pasteur (São Paulo) 2007. Disponível em http://www.pasteur.saude.sp.gov.br/menu.htm. Acessado em 22/04/2007.

62 IPVDF - Instituto de Pesquisas Veterinárias Desidério Finamor) 1981. Equipe de Virologia. Laboratório de Raiva. Registros de laboratório (dados não publicados). 
63 IPVDF - Instituto de Pesquisas Veterinárias Desidério Finamor) 1988. Equipe de Virologia. Laboratório de Raiva. Registros de laboratório (dados não publicados).

64 IPVDF - Instituto de Pesquisas Veterinárias Desidério Finamor) 2007. Equipe de Virologia. Laboratório de Raiva. Registros de laboratório (dados não publicados).

65 Iseni F., Barge A., Baudin F., Blondell D. \& Ruigrok R.W.H. 1998. Characterization of rabies virus nucleocapsids and recombinant nucleocapsid-like structures. Journal of General Virology 79: 2909-2919.

66 Ito M., Arai Y. T., Itou T., Sazai T., Ito F.H., Takasaki T. \& Kurane 2001. Genetic characterization and geografic distribution of rabies virus isolates in Brazil: identification of two reservoirs, dogs and vampire bats. Virology. 284: $214-222$.

67 Ito M., Itou T., Shoji Y., Sazai T., Ito F.H., Arai Y. T., Takasaki T. \& Kurane I. 2003. Discrimination between dog-related and vampire bat-related rabies viruses in Brazil by strain-specific reverse transcriptase-polymerase chain reaction and restriction fragment length polimorphism analysis. Journal of Clinical Virology. 26: 317-330.

68 Iverson L.E. \& Rose J.K. 1981. Localized attenuation and discontinuous synthesis during vesicular stomatitis virus transcription. Cell. 23: 477-484.

69 Iwasaki, Y. 1991. Spread of virus within the central nervous system. In: The Natural History of Rabies. Boca Raton: CRC Press, pp.121-132.

70 Jacob Y., Badrane H., Ceccaldi P.E. \& Tordo N. 2000. Cytoplasmic Dynein LC8 Interacts with Lyssavirus Phosphoprotein. Journal of Virology. 74: 10217-10222.

71 Johnson N., Brookes S.M., Fooks A.R. \& Ross R.S. 2005. Review of human rabies cases in the UK and in Germany. The Veterinary Record. 157: 715.

72 Kawano H., Mifune K., Ohuchi M., Mannen K., Cho S., Hiramatsu K. \& Shichijo A. 1990. Protection against rabies in mice by a cytotoxic T cell clone recognizing the glycoprotein of rabies virus. Journal of General Virology. 71: 281-287.

73 Kimura L.M.S., Dantas Junior J.V., Moura W.C., Kotait I., Marin V.A. \& Brandao P.E. 2006. Reação em cadeia da polimerase como recurso ao diagnóstico da raiva. Revista Brasileira de Medicina Veterinária. 28: 104-109.

74 King A.A. 1991. Studies on the antigenic relationships of rabies and rabies-related viruses using anti-nucleoprotein monoclonal antibodies. 371f PhD Tese. University of Surrey, Guildford, UK.

75 Kissi B., Tordo N. \& Bourhy H. 1995. Genetic polymorphism in the rabies virus nucleoprotein gene. Virology. 209: 526-537.

76 Kobayashi Y., Sato G., Shoji Y., Sato T., Itou T., Cunha E.M., Samara S.I., Carvalho A.A., Nociti D.P., Ito F.H. \& Sakai T. 2005. Molecular epidemiological analysis of bat rabies viruses in Brazil. Journal of Veterinary Medical Science. 67: 647-652.

77 Kobayashi Y., Ogawa A., Sato G., Sato T., Itou T., Samara S.I., Carvalho A.B., Nociti D.P., Ito F.H. \& Sakai T. 2006. Geographical distribution of vampire bat-related cattle rabies in Brazil. Journal of Veterinary Medical Science. 68: 1097-1100.

78 Kotait I. 1996. Infecção de morcegos pelo vírus da raiva. Boletim do Instituto Pasteur (São Paulo). 1: 51-58.

79 Doc Eletrônico (internet) Kotait, I. (org.) 1998 Manual Técnico do Instituto Pasteur. Número 7 - Manejo de quirópteros em áreas urbanas. Instituto Pasteur: São Paulo. 45 pp. Disponível em: http://www.pasteur.saude.sp.gov.br/informacoes/ informacoes_publicacoes.htm. Acessado em: 22/04/2007.

80 Doc Eletrônico (internet) Kotait I. 2006. Programa de Prevenção e Controle da Raiva Transmitida por Morcegos em Áreas Urbanas Boletim Epidemiológico Paulista. 3(36). Disponível em: http://www.cve.saude.sp.gov.br/agencia/bepa36_morcego.htm. Acessado em 22/04/2007.

81 Kusmin I.V., Orciari L.A.,Arai Y.T., Smith J.S., Hanlon C.A., Kameoka Y. \& Rupprecht C.E. 2003. Bat lyssavirus (Aravan and Khujand) from Central Asia: phylogenetic relationships according to N, P and G gene sequences. Virus Research. 97 : 65-79.

82 Kusne S. \& Smilack J. 2005. Transmission of rabies virus from organ donor four transplantion recipients. Liver Transplant. 11: $1295-1297$.

83 Lafon M. 2005. Rabies virus receptors. Journal of Neurovirology 11: 82-87.

84 Lentz T.L., Burrage T.G., Smith A.L., Crick J. \& Tignor G.H. 1982. Is the acetylcholine receptor a rabies virus receptor? Science. 215: 182-184.

85 Lépine P. \& Atanasiu P. 1996. Histopathological Diagnosis. In: Laboratory Techniques in Rabies. Meslin F.X., Kaplan M.M., Koprowski (Eds). 4th edn. Geneva: World Health Organization, pp.66-79.

86 Lima E.F., Riet-Correa F., Castro R.S., Gomes A.B. \& Lima F.S. 2005. Clinical signs, distribution of the lesions in the central nervous system and epidemiology of rabies in northeastern Brazil. Pesquisa Veterinária Brasileira. 25: $250-264$.

87 Lindenmann J. 2007. Evolution in action: a virological experiment of long duration. Microbiology Today. 34: $24-27$. 
88 Lodmell D.L., Esposito J.J. \& Ewalt L.C. 1993. Rabies virus anti-nucleoprotein antibody protects against rabies virus challenge in vivo and inhibits rabies virus replication in vitro. Journal of Virology. 67: 6080-6086.

89 Lord R.D., Fuenzalida E., Delpietro H., Larghi O.P., Díaz A.M.O. \& Lázaro L. 1975. Observations on the epizootiology of vampire bat rabies. Bulletin of the Pan American Health Organization. 9: 189-195.

90 Doc Eletrônico (internet) MAPA - Ministério da Agricultura, Pecuária e Abastecimento Disponível em: http://www. agricultura.gov.br/portal/page?_pageid=33,3271386\&_dad=portal\&_schema=PORTAL Acessado em 06/04/2007

91 Margreth A. 2003. Adelchi Negri and schools of general pathology in Italy between the end of the nineteenth and beginning of the twentieth century. Rendiconti Lincei Scienze Fisiche e Naturalis. 14: 251-262.

92 Marston D.A., McElhinney L.M., Johnson N., Müller T., Conzelmann K.K., Tordo N. \& Fooks A.R. 2007. Comparative analysis of the full genome sequence of European bat lyssavirus type 1 and 2 with other lyssaviruses and evidence for a conserved transcription termination and polyadeylation motif in the G-L 3' non-translated region. Journal of General Virology. 88: 1302-1314.

93 Martorelli L.F., Aguiar E.A.,Almeida M.F., Silva M.M. \& Novaes E.C. 1995. Isolation of rabies virus from the insectivorous bat Myotis nigricans Revista de Saúde Pública. 29: 140-141.

94 Matsumoto S. 1962. Electron microscopy of nerve cells infected with street rabies virus. Virology. 17:156-158.

95 Mayr A. \& Guerreiro M.G. 1972. Vírus da raiva. In: Virologia Veterinária. 2. ed. Porto Alegre: Sulina, 437p.

96 McLean R.G. 1975. Raccoon rabies. In: Baer G.M. (Ed). The natural history of rabies. New York: Academic Press, pp.53-77.

97 Mebatsion T., Sillero-Zubiri C., Gottelli D. \& Cox J.H. 1992. Detection of rabies antibody by ELISA and RFFIT in unvaccinated dogs and in the endangered Simien jackal (Canis simensis) of Ethiopia. Zentralbl Veterinarmed B. 39: 233-235.

98 Mebatsion T., Konig M. \& Conzelmann K.K. 1996. Budding of rabies virus particles in the absence of the spike glycoprotein. Cell. 84: 941-951.

99 Doc Eletrônico (internet) Ministério da Saúde. 2006. Raiva Humana - Distribuição de casos confirmados por Unidade Federada: Disponível em: portal.saude.gov.br/portal/arquivos/pdf/raiva_2006.pdf. Acessado em 14/05/2007.

100 Morais N.B., Rolim B. N., Chaves H.H.M., Brito-Neto J. \& Silva L.M. 2000. Rabies in tamarins (Callithrix jacchus) in the state of Ceara, Brazil, a distinct viral variant? Memorias do Instituto Oswaldo Cruz. 95: 609-610.

101 Morimoto K., Hooper D.C., Carbaugh H., Fu Z.F., Koprowski H. \& Dietzschold B. 1998. Rabies virus quasispecies: Implications for pathogenesis. Proceedings of the National Academy of Sceiences USA. 95: 3152-3156.

102 Morimoto K., Hooper D.C., Spitsin S., Koprowski H. \& Dietzschold B. 1999. Pathogenicity of different rabies virus variants inversely correlates with apoptosis and rabies virus glycoprotein expression in infected primary neuron cultures. Journal of Virology. 73: 510-518.

103 Nadin-Davis S.A. 1998. Polymerase chain reaction protocols for rabies virus discrimination. Journal of Virology Methods. 75: $1-8$.

104 Nadin-Davis S.A., Sheen M., Abdel-Malik M., Elmgren L., Armstrong J. \& Wandeler A.I. 2000. A panel of monoclonal antibodies targeting the rabies virus phosphoprotein identifies a highly variable epitope of value for sensitive strain discrimination. Journal of Clinical Microbiology. 38: 1397-1403.

105 Nadin-Davis S.A., Abdel-Malik M., Armstrong J. \& Wandeler A.I. 2002. Lyssavirus $P$ gene characterization provides insights into the phylogeny of the genus and identifies structural similarities and diversity within the encoded phosphoprotein. Virology. 298: 286-305.

106 Negri A. 1903. Beitrag zum Studium de Aetiologie der Tollwuth. Zeitschrift Für Hygiene Und Infektionskrankheiten. 43: 507-528.

107 Nicholson K.G. \& Prestage H. 1982. Enzyme linked immunosorbent assay: a rapid reproducible test for measurement of rabies antibody. Journal of Medical Virology. 9: 43-45.

108 Oliveira A.N., Andrade M.C.R. Silva M.V., Moura W.C. \& Contreiras E.C. 2000. Immune response in cattle vaccinated against rabies . Memórias do Instituto Oswaldo Cruz. 95: 83-88.

109 Passos E.C., Carrieri M.L., Dainovskas E., Camara M.\& Silva M.M. 1998. Isolation of rabies virus from an insectivorous bat, Nyctinomops macrotis, in southeast Brazil. Revista de Saúde Pública. 32: 74-76.

110 Perrin P., Versmisse P., Delagneau J.F., Lucas G., Rollin P.E. \& Sureau P. 1986. The influence of the type of immunosorbent on rabies antibody EIA; advantages of purified glycoprotein over whole virus. Journal of Biological Standardization. 14: $95-102$.

111 Piza A.S., Santos J.L., Chaves L.B. \& Zanetti C.R. 1999. An ELISA suitable for the detection of rabies virus antibodies in serum samples from human vaccinated with either cell-culture vaccine or suckling-mouse-brain vaccine. Revista do Instituto de Medicina Tropical de São Paulo. 41: 39-43. 
112 Queiroz L.H., Morinishi C.K. \& Nunes C.M. 2004. Diagnóstico diferencial entre a raiva e a cinomose canina em amostras de cérebro de cães examinadas no período de 1998 a 2001 na região de Araçatuba, SP, Brasil. Arquivos do Instituto Biológico. 71: 317-321.

113 Rebhun W.C. 2000. Doenças do gado leiteiro. São Paulo. $1^{\text {a }}$ ed. Editora Roca, 642 p.

114 Rhodes C.J., Atkinson R.P.D., Anderson R.M. \& Macdonald D.W. 1998. Rabies in Zimbabwe: reservoir dogs and the implications for disease control. Philosophical Transactions of the Royal Society of London B. 353: 999-1010.

115 Ridrigues F.M., Nagata C.A., Peixoto Z.M. \& Nilsson M.R. 1975. Isolation of rabies virus from an insectivorous bat Molossus obscurus (Geoffroy, 1805), in the state of Sao Paulo Arquivos do Instituto Biológico. 42: 193-196.

116 Rigo L. \& Honer M. 2006. Titulação de anticorpos contra o vírus da raiva em cães, em Campo Grande, MS, na Campanha Anti-Rábica de 2003. Revista da Sociedade Brasileira de Medicina Tropical. 39: 553-555.

117 Rodrigues da Silva A.C., Caporale G.M., Goncalves C.A., Targueta M.C., Comin F., Zanetti C.R. \& Kotait I. 2000. Antibody response in cattle after vaccination with inactivated and attenuated rabies vaccines. Revista do Instituto de Medicina Tropical de Sao Paulo. 42: 95-98.

118 Roehe P.M., Cunha A.C., Rodrigues R.R., Gonçalves A.R. \& Ribeiro C.L.G. 1985. Diagnóstico laboratorial da raiva no Rio Grande do Sul, Brasil. Boletin de la Oficina Sanitaria Panamericana. 102: 464-475.

119 Roehe P.M., Cunha A.C. \& King A. 1987. Niveis de anticorpos neutralizantes em bovinos vacinados contra a raiva. Pesquisa Veterinária Brasileira. 7: 63-65.

120 Roehe P.M., Pantoja L.D., Shaefer R., Nardi N.B. \& King,A.A. 1997 Analysis of Brazilian rabies virus isolated with monoclonal antibodies to Lyssavirus antigens. Revista de Microbiologia. 28: 288-292.

121 Romijn P.C., Van der Heide R., Cattaneo C.A., Silva R.D.E.C. \& Van der Poel W.H. 2003. Study of lyssaviruses of bat origin as a source of rabies for other animal species in the State of Rio de Janeiro, Brazil. American Journal of Tropical Medicine and Hygiene. 69: 81-86.

122 Rosatte R.C. \& Gunson J.R. 1984. Presence of neutralizing antibodies to rabies virus in striped skunks from areas free of skunk rabies in Alberta. Journal of Wildlife Diseases. 20: 171-176.

123 Ruschi A. 1956. Dois casos de sanguivorismo de Desmodus rotundus (E.Geoffroy) e Dyphilla ecaudata spix, no homem e outras observações sobre quirópteros hematófagos e acidentalmente hematófagos. Boletim do DIPAN (Secretaria da Agricultura do Rio Grande do Sul). 96: 6-16.

124 Sacramento D., Bourhy H. \& Tordo N. 1991. PCR technique as an alternative method for diagnosis and molecular epidemiology of rabies virus. Molecular Cell Probes, 5: 229-240.

125 Sanches A.W.D., Langohr I.M., Stigger A.L. \& Barros C.S.L. 2000. Doenças do sistema nervoso central em bovinos no Sul do Brasil. Pesquisa Veterinária Brasileira. 20: 113-118.

126 Sato G., Itou T., Shoji Y., Miura Y., Mikami T., Ito M., Kurane I., Samara S.I., Carvalho A.A., Nociti D.P., Ito F.H. \& Sakai T. 2004. Genetic and phylogenetic analysis of glycoprotein of rabies virus isolated from several species in Brazil. Journal of Veterinary Medical Science. 66: 747-753.

127 Sato G., Tanabe H., Shoji Y., Itou T., Ito F. H., Sato T. \& Sakai, T. 2005. Rapid discrimination of rabies viruses isolated from various host species in Brazil by multiplex reverse transcription-polymerase chain reaction. Journal of Clinical Virology. 33: 267-273.

128 Sato G., Kobayashi Y., Shoji Y., Sato T., Itou T., Ito F.M., Santos H.P., Brito C.J. \& Sakai T. 2006. Molecular epidemiology of rabies from Maranhão and surrounding states in the northeastern region of Brazil. Archives of Virology. 151: $2243-2251$.

129 Schaefer R., Caldas E., Schmidt E., KingA.A. \& Roehe P.M. 2002. First case of cat rabies in Southern Brazil for 11 years. Veterinary Record. 150: 216-217.

130 Schaefer R., Batista H.B.C.R., Franco A.C., Rijsewijk F.A.M. \& Roehe P.M. 2005. Studies on antigenic and genomic properties of Brazilian rabies virus isolates. Veterinary Microbiology. 107: 161-170.

131 Schneider L.G. 1991. Spread of virus within the central nervous system. In Baer, G.M. The Natural History of Rabies. 2nd ed. Boca Raton, USA. RCR Press. p. 199-216.

132 Schneider M.C., Aron J., Santos-Burgoa C., Uieda W. \& Ruiz-Velazco S. 2001. Common vampire bat attacks on humans in a village of the Amazon region of Brazil. Cadernos de Saúde Pública. 17: 1531-1536.

133 Schneider M.C., Almeida G.A., Souza L.M., Morares N.B. \& Diaz R.C. 1996. Controle da raiva no Brasil de 1980 a 1990. Revista de Saúde Pública. 30: 196-203.

134 Shankar V., Dietzschold B. \& Koprowski H. 1991. Direct entry of rabies virus into central nervous system without prior local replication. Journal of Virology. 65: 2736-2738. 
135 Shoji Y., Kobayashi Y., Sato G., Gomes A.A., Itou T., Ito F. H. \& Sakai T. 2006. Genetic and phylogenetic characterization of rabies virus isolates from wildlife and livestock in Paraiba, Brazil. Acta Virologica. 50: 33-37.

136 Doc Eletrônico (internet) SIEPI (Sistema de Informação Epidemiológica). 2007. PANAFTOSA, OPAS, OMS. Disponível em: http://siepi.panaftosa.org.br/Anuais.aspx Acessado em 09/04/2007.

137 Sikes R.K. 1962. Pathogenesis of rabies in wildlife: 1 . Comparative effect of varying doses of rabies virus inoculated into foxes and skunks. American Journal of Veterinary Research. 23: 1041-1047.

138 Silva A.C.R., Caporale G.M.M., Gonçalves C.A., Targueta M.C., Comin F., Zanetti C.R. \& Kotait I. 2000. Antibody response in cattle after vaccination with inactivated and attenuated rabies vaccines. Revista do Instituto de Medicina Tropical. 42: 95-98.

139 Doc Eletrônico (internet) SINDAM. 2007. Vacinas: venda bate recorde. Disponível em: http://www.sindan.org.br/informacoes/ noticia.aspx?codigonoticia=538\&tipo=S. Acessado em: 07/04/2007

140 Smith J.S. 1989. Rabies virus epitopic variation: use in ecologic studies. Advances in Virus Research, 36: $215-253$.

141 Smith J., Yager P.A. \& Baer G.M. 1973. A rapid reproducible test for determining rabies neutralizing antibodies. Bulletin of the Word Health Organization. 48: 535-541.

142 Smith J.S., Fishbein D.B., Rupprecht C. \& Clark K. 1991. Unexplained rabies in three immigrants in the United States. The New England Journal of Medicine. 234: 205-211.

143 Smith J.S., Seidel H.D. \& Warner C.K. 1992. Epidemiology and historical relationships among 87 rabies virus isolates determined by limited sequence analysis. Journal of Infectious Diseases. 166: 296-307.

144 Smith J.S. 1996. New aspects of rabies with emphasis on epidemiology, diagnosis and prevention of diseases in the United States. Clinical Microbiology Reviews. 9: 166-176.

145 Smith J.S., Yager P.A. \& Baer G.M. 1996. A rapid fluorescent focus inhibition test (RFFIT) for determining rabies virusneutralizing antibody. In: Laboratory Techniques in Rabies. Meslin F.X., Kaplan M.M. \& Koprowski H. (Eds). 4th edn. Geneva: World Health Organization, pp.181-189.

146 Soares R.M., Bernardi F., Sakamoto S.M., Heinemann M.B., Cortez A., Alves L.M., Meyer A.D., Ito F.H. \& Richtzenhain L.J. 2002. A heminested polymerase chain reaction for the detection of brazilian rabies isolates from vampire bats and herbivores. Memórias do Instituto Oswaldo Cruz. 97: 109-111.

147 Spilki F.R., Franco A.C., Teixeira M.B., Esteves P.A., Schaefer R., Schmidt E., Lemos R.A. \& Roehe P.M. 2003. Bovine herpesvirus type 5 (BHV-5) in a calf with rabies. 2002. Pesquisa Veterinária Brasileira. 23: 1-4.

148 Srinivasan A., Burton E.C., Kuehnert M.J., Rupprecht C., Sutker W.L., Ksiazek T.G., Paddock C.D., Guarner J., Shieh W., Goldsmith C., Hanlon C.A., Zoretic J., Fischbach B., Niezgoda M., El-Feky W.H., Orciari L., Sanchez E.Q., Likos A., Klintmalm G.B., Cardo D., LeDuc J., Chamberland M.E., Jernigan D.B. \& Zaki S.R. 2005. Transmission of rabies virus from an organ donor to four transplant recipients. New England Journal of Medicine. 352: 1103-1111.

149 Steele J.H. 1975. History of rabies. In: The Natural History of Rabies. Baer G.M. (Ed). 2nd edn. Boca Raton: RCR Press, pp.1-29.

150 Sugamata M., Miyazawa M., Mori S., Spangrude G.J., Ewalt L.C. \& Lodmell D.L. 1992. Paralysis of street rabies virus-infected mice is dependent on T lymphocytes. Journal of Virology. 66: 1252-1260.

151 Teixeira T.F., Batista H.B.C.R., Schmidt E. \& Roehe P.M. 2005. Estudo antigênico de amostras do virus da raiva isoladas no Rio Grande do Sul, Brasil. Acta Scientiae Veterinariae. 33: 271-275.

152 Tsiang H. 1993. Pathophysiology of rabies virus infection of nervous system. Advances in Virus Research. 42: 375-412.

153 Thoulouze M.I., Lafage M., Schachner M., Hartmann U., Cremer H. \& Lafon M. 1998. The Neural Cell Adhesion Molecule Is a Receptor for Rabies Virus. Journal of Virology. 72: 7181-7190.

154 Tordo N., Poch O., Ermine A., Keith G. \& Rougeon F. 1986. Walking along the rabies genome: is the large G-L intergenic region a remnant gene? Proceedings of the National Academy of Sciences USA. 83: 3914-3918.

155 Tordo N. \& Poch O. 1988. Structure of rabies virus. In: Rabies. Campbell J.B. \& Charlton K.M. (Eds). Boston: Kluwer Academic Publishers, pp.25-45.

156 Tordo N. 1996. Characteristics and molecular biology of the rabies virus. In: Laboratory Techniques in Rabies. Meslin F.X., Kaplan M.M., Koprowski H. (Eds). 4th edn. Geneva: World Health Organization, pp.28-51.

157 Torres S. 1934. Morcegos da família Desmodontidae e seu papel na transmissão de moléstias aos animais. Revista do Departamento Nacional de Produção Animal. 1: 25-33.

158 Torres S. \& Queiroz de Lima E. 1936. A raiva e os morcegos hematófagos. Revista do Departamento Nacional de Produção Animal. 3: 165-174. 
159 Tuffereau C., Benejean J., Blondel D., Kieffer B. \& Flamand A. 1998. Low-affinity nerve-growth factor receptor (P75NTR) can serve as a receptor for rabies virus. EMBO Journal. 17: 7250-7259.

160 Uieda W., Harmani N.M. \& Silva M.M. 1995. Rabies in insectivorous (Molossidae) bats of southeastern Brazil. Revista de Saúde Pública. 29: 393-397.

161 Velasco-Villa A., Orciari L.A., Juarez-Islas V., Gomez-Sierra M., Padilla-Medina I., Flisser A., Souza V., Castillo A., Franka R., Escalante-Mane M., Sauri-Gonzalez I. \& Rupprecht C.E. 2006. Molecular diversity of rabies viruses associated with bats in Mexico and other countries of the Americas Journal of Clinical Microbiology 44: 1697-710.

162 Warrell M.J. \& Warrell D.A. 2004. Rabies and other lyssavirus diseases. The Lancet. 363: 959-969.

163 Webster G.A. \& Casey G.A. 1996. Virus isolation in neuroblastoma cell culture. In: Laboratory Techniques in Rabies. Meslin F.X., Kaplan M.M. \& Koprowski H. (Eds). 4th edn. Geneva: World Health Organization, pp.96-103.

164 Webster L.T. \& Dawson J.R. 1935 Early diagnosis of rabies by mouse inoculation. Measurement of humoral immunity to rabies by mouse protection test. Proceedings of the Society for Experimental Biology and Medicine. 32: 570-573.

165 Weiland F., Cox J.H., Meyer S., Dahme E., \& Reddehase M.J. 1992. Rabies virus neuritic paralysis: immunopathogenesis of nonfatal paralytic rabies. Journal of Virology. 66: 5096-5099.

166 Doc Eletrônico (internet) WHO 2004 Expert consultation on rabies. Technical report series 931. WHO. Disponível em: http://www.who.int/rabies/ExpertConsultationOnRabies.pdf. Acessado em 04/04/2007.

167 Wunner W.H. 1991. The chemical composition and molecular structure of rabies viruses. In Baer G. M.(Ed.). The Natural History of Rabies. Boca Raton: CRC Press, pp. 31-67.

168 Wiktor T.J. \& Koprowski H. 1978. Monoclonal antibodies against rabies virus produced by somatic cell hybridization: detection of antigenic variants. Proceedings of the National Academy of Sciences USA. 75: 3938-3942. 